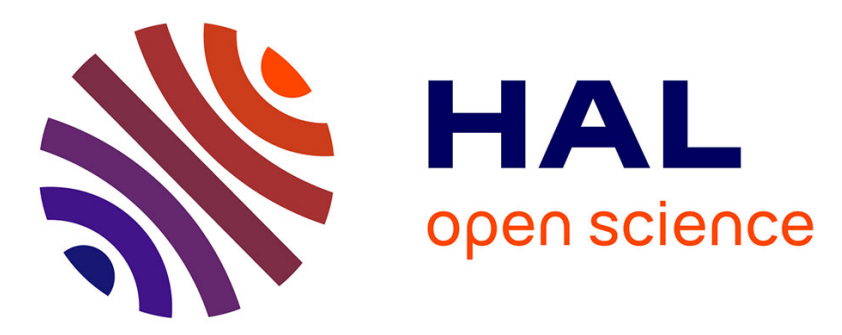

\title{
High-Yielding Diastereoselective syn -Dihydroxylation of Protected HBO: An Access to D-(+)-Ribono-1,4-lactone and 5- $\mathrm{O}$-Protected Analogues
}

\author{
Maxime Moreaux, Guillaume Bonneau, Aurélien Peru, Fanny Brunissen, \\ Marine Janvier, Arnaud Haudrechy, Florent Allais
}

\section{To cite this version:}

Maxime Moreaux, Guillaume Bonneau, Aurélien Peru, Fanny Brunissen, Marine Janvier, et al.. HighYielding Diastereoselective syn -Dihydroxylation of Protected HBO: An Access to D-(+)-Ribono-1,4lactone and 5- O -Protected Analogues. European Journal of Organic Chemistry, 2019, 2019 (7), pp.1600-1604. 10.1002/ejoc.201801780 . hal-02052678

\section{HAL Id: hal-02052678 \\ https://hal.science/hal-02052678}

Submitted on 21 Apr 2020

HAL is a multi-disciplinary open access archive for the deposit and dissemination of scientific research documents, whether they are published or not. The documents may come from teaching and research institutions in France or abroad, or from public or private research centers.
L'archive ouverte pluridisciplinaire HAL, est destinée au dépôt et à la diffusion de documents scientifiques de niveau recherche, publiés ou non, émanant des établissements d'enseignement et de recherche français ou étrangers, des laboratoires publics ou privés. 


\title{
High yielding diastereoselective syn-dihydroxylation of protected HBO: an access to D-(+)-ribono-1,4-lactone and 5-O-protected analogues
}

\author{
Maxime Moreaux, ${ }^{[a, b]}$ Guillaume Bonneau, ${ }^{[a, b]}$ Aurélien Peru, ${ }^{[a]}$ Fanny Brunissen, ${ }^{[a]}$ Marine \\ Janvier, ${ }^{[a]}$ Arnaud Haudrechy*[b] and Florent Allais*[a]
}

[a] M. Moreaux, G. Bonneau, A. A. M. Peru, F. Brunissen, Dr. M. Janvier and Prof. F. Allais*

Chaire Agro-Biotechnologies Industrielles (ABI)

AgroParisTech

CEBB 3 rue des Rouges Terres 51110 Pomacle, France

E-mail: florent.allais@agroparistech.fr

[b] M. Moreaux, G. Bonneau, Prof. A. Haudrechy*

Institut de Chimie Moléculaire de Reims, UMR CNRS 7312, SFR Condorcet FR CNRS 3417

Université de Reims Champagne-Ardenne

BP 103951687 Reims Cedex 2, France

E-mail: arnaud.haudrechy@univ-reims.fr

Supporting information for this article is given via a link at the end of the document.

\begin{abstract}
A diastereoselective chemo-enzymatic synthetic pathway to D-(+)-ribono-1,4-lactone, a versatile chiral sugar derivative widely used for the synthesis of various natural products, has been designed from cellulose-based levoglucosenone (LGO). This route involves a sustainable Baeyer-Villiger oxidation of LGO to produce enantiopure (S)- $\gamma$-hydroxymethyl- $\alpha, \beta-$ butenolide (HBO) that is further functionalized with various protecting groups to provide 5-O-protected D-(+)-ribono-1,4-lactones. The resulting 5-O-protected lactones then undergo a diastereoselective and high yielding syn-dihydroxylation of the $\alpha, \beta$ unsaturated lactone moiety followed by a deprotection step to give D-(+)-ribono-1,4-lactone. Through this 4-step synthetic route from LGO, D-(+)-ribono-1,4-lactone is obtained with d.r. varying from 82:18 to $97: 3$ and in overall yields between 32 and $41 \%$ depending on the protecting group used. Moreover, valuable synthetic intermediates 5-O-tert-butyldimethylsilyl-, 5-O-tertbutyldiphenylsilyl- as well as 5-O-benzyl-ribono-1,4-lactones are obtained in 3 steps from LGO in 58,61 and $40 \%$, respectively.
\end{abstract}

\section{Introduction}

In a context of increasing scarcity and price of fossil resources, and also more drastic regulations such as the REACH regulation, the use of alternative renewable resources has raised a growing interest in the scientific community. The production of valuable chemicals from renewable biomass has been largely developed in the last decades, with the aim of offering new sustainable efficient procedures as alternative routes to traditional synthetic pathways. ${ }^{1}$ In this context, an interesting alternative is the valorization of lignocellulose, which is the most abundant and bio-renewable biomass on earth. ${ }^{2}$ The catalytic fast pyrolysis (CFP) of lignocelluloses has already been deeply studied for the production of target products in high yields. ${ }^{3}$ Levoglucosenone (LGO) is one of the products that can be produced from lignocellulose CFP (Scheme 1). The structure of this synthon is particularly interesting, due to the presence of one natural chiral center preserved from cellulose, and the presence of two functionalisable moieties ( $\alpha, \beta$-unsaturated ketone and protected aldehyde functionality). According to these properties, LGO constituted a synthon of choice for the production of several valuable products such as natural products, nucleosides, anticancer drugs and building blocks. ${ }^{4-8}$

Among the compounds obtained from LGO, the unsaturated chiral $\gamma$-lactone (S)- $\gamma$-hydroxymethyl- $\alpha, \beta$-butenolide (HBO, Scheme 1) has found numerous applications as a key intermediate for the synthesis of drugs (such as Burseran or Isostegane), ${ }^{9,10}$ flavors ${ }^{11,12}$ and antiviral agents against HIV or hepatitis B virus. ${ }^{13-15}$ Our team recently developed cost-efficient, low toxicity and green syntheses of optically pure HBO from LGO using Baeyer-Villiger oxidations. ${ }^{16-19}$ Dedicated to the development of valuable applications of this platform molecule, our team then designed and optimized the chemo-enzymatic synthesis of (S)-dairy lactone, ${ }^{12}$ a flavor used in food applications for its fruity odor and creamy dairy-like taste.

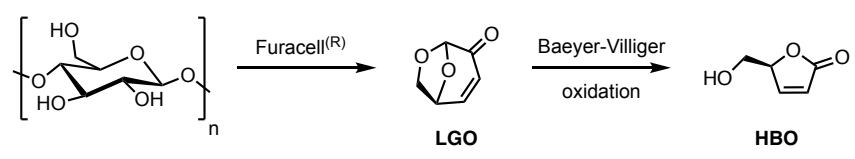


D-(+)-ribono-1,4-lactone, a rather costly rare sugar (ca. 50€/g) present in leaves of Listea japonica, displays an interesting vicinal 1,2-cis-diol and has been used for the synthesis of various natural or synthetic bioactive molecules ${ }^{20}-$ such as Herbarumin $\mathrm{I}^{21}$ or (+)-Varitriol ${ }^{22}$ (Scheme 2).

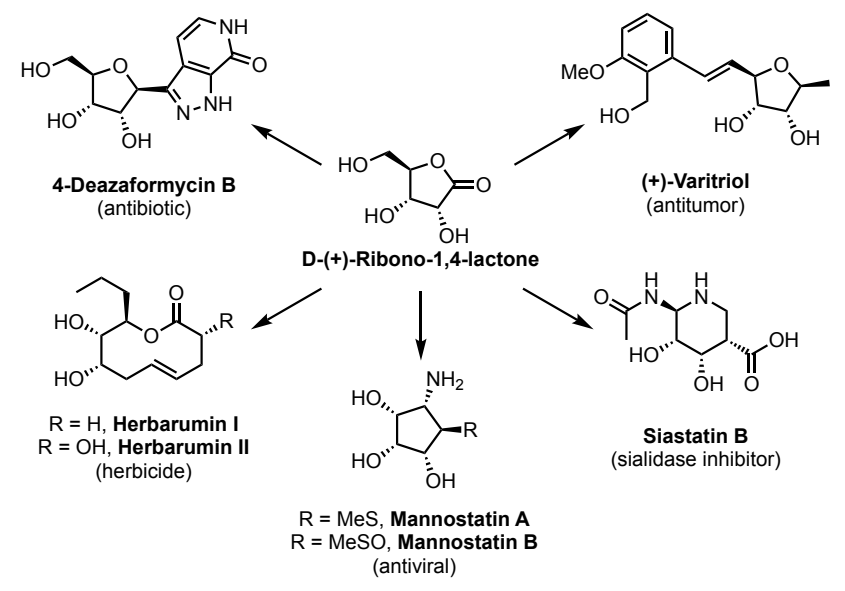

Scheme 2. Some molecules of interest accessible from D-(+)-ribono-1,4-lactone

D-(+)-ribono-1,4-lactone can be prepared in ca. $65 \%$ yield through the molecular bromine-mediated oxidation of D-ribose, ${ }^{23}$ a costly sugar (ca. $400 € / \mathrm{kg}$ ). Another route consists in first protecting the primary alcohol of HBO with bulky groups to hinder the upper face of the molecule, then performing the asymmetric syn-dihydroxylation of the $\alpha, \beta$-unsaturation in presence of $\mathrm{KMnO}_{4}$ (1.25 eq) and dicyclohexano-18-crown-6 ether (10 mol\%) in $\mathrm{CH}_{2} \mathrm{Cl}_{2}$ at $-42{ }^{\circ} \mathrm{C} .{ }^{24}$ Although this procedure provides 5-O-protected D-(+)-ribono-1,4-lactone in d.r. between 12:1 and 50:1 depending on the protecting group used, the oxidizing agent is used in stoichiometric amount, the yields remain low to average $(<66 \%)$ - due to overoxidation of the resulting diol - and energydemanding low temperature control is required. In this paper, we will describe a high yielding syn-dihydroxylation of 5-Oprotected HBO, and discuss the influence of the protecting group on its diastereoselectivity, as well as the final deprotection steps required to access D-(+)-ribono-1,4-lactone (Scheme 3).

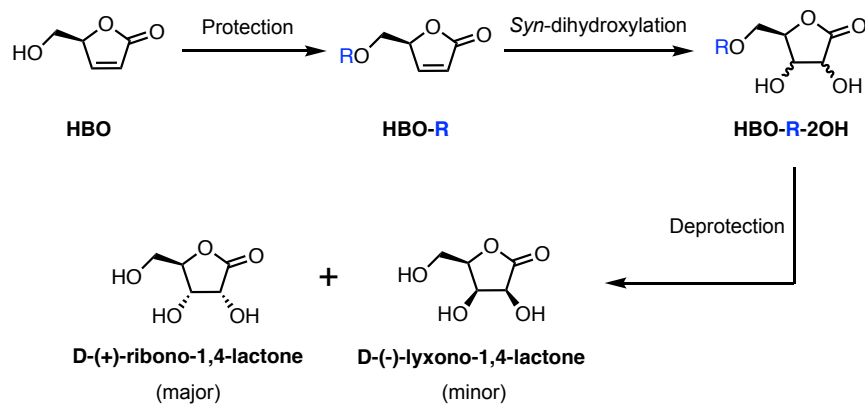

Scheme 3. Synthetic strategy to convert HBO into (+)-D-ribono-1,4-lactone

\section{Results and Discussion}

The first step of the synthetic route to D-(+)-ribono-1,4-lactone consisted in the efficient and straightforward $\mathrm{H}_{2} \mathrm{O}_{2}$-mediated Baeyer-Villiger oxidation of LGO into HBO (Scheme 4). ${ }^{19}$ Validated at the kilo scale, this sustainable synthetic procedure provides HBO in $84 \%$ yield. Protection of HBO was performed using benzyl (Bn), tert-butyldimethylsilyl (TBDMS), as well as tert-butyldiphenylsilyl (TBDPS) protecting groups. Silyl ethers HBO-TBDMS and HBO-TBDPS were obtained under classical conditions (silyl chloride, imidazole, DMF) in 78 and $82 \%$ yields, respectively. For the benzyl ether HBO-Bn, acidic conditions using benzyl 2,2,2-trichloroacetimidate as benzyl donor ${ }^{25}$ were applied and lead to HBO-Bn in $53 \%$ yield.

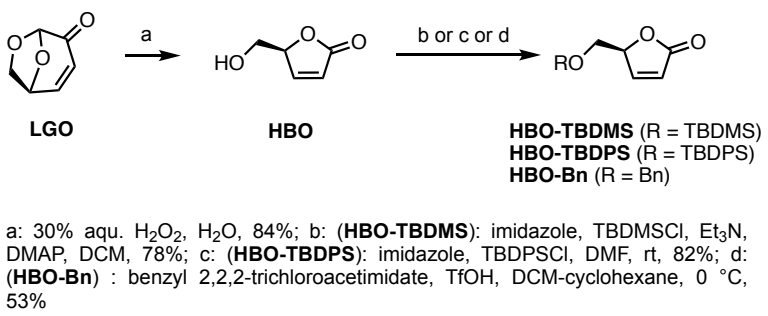


Olefin dihydroxylation is a common reaction in the synthesis of pharmaceuticals and natural products. The Sharpless asymmetric dihydroxylation, ${ }^{26,27}$ involving osmium catalyst, has been widely used due to its high stereospecificity and enantioselectivity.

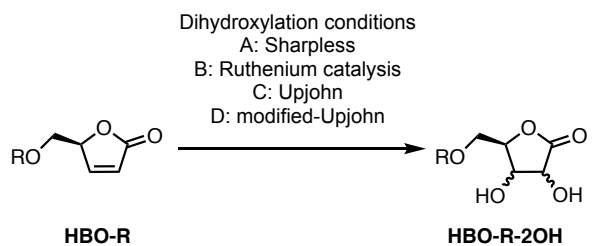

Table 1. syn-Dihydroxylation using Sharpless conditions, $\mathrm{RuCl}_{3}$ catalysis, Upjohn and modified-Upjohn conditions.

\begin{tabular}{|c|c|c|c|c|c|}
\hline $\begin{array}{c}\text { Entr } \\
y\end{array}$ & $\begin{array}{l}\text { Substrate } \\
\text { (HBO-R) }\end{array}$ & Meth. ${ }^{[b]}$ & Yield (\%) $)^{[\mathrm{b}]}$ & $\begin{array}{l}\text { d.r. }(\%) \\
\text { NMR } \\
\text { d] }\end{array}$ & $\begin{array}{l}\text { d.r. }(\%) \\
\text { HPLC[c,e] }\end{array}$ \\
\hline 1 & $\begin{array}{l}\text { HBO- } \\
\text { TBDMS }\end{array}$ & A & 0 & - & - \\
\hline 2 & & B & 60 & $94: 6$ & $97: 3$ \\
\hline 3 & & C & 50 & $91: 9$ & 91:9 \\
\hline 4 & & D & 88 & $93: 7$ & $95: 5$ \\
\hline 5 & HBO-TBDPS & A & 0 & - & - \\
\hline 6 & & B & 62 & $94: 6$ & $94: 6$ \\
\hline 7 & & C & 55 & $95: 5$ & $92: 8$ \\
\hline 8 & & D & 89 & $97: 3$ & $94: 6$ \\
\hline 9 & HBO-Bn & A & 0 & - & - \\
\hline 10 & & B & 60 & $80: 20$ & $88: 12$ \\
\hline 11 & & C & 12 & $78: 22$ & $86: 14$ \\
\hline 12 & & D & 75 & $82: 18$ & $83: 17$ \\
\hline
\end{tabular}

A: AD-mix- $\beta\left(\mathrm{K}_{2} \mathrm{OsO}_{4}\right.$ or $\mathrm{OsO}_{4}, \mathrm{~K}_{3} \mathrm{Fe}(\mathrm{CN})_{6}$, chiral ligand (DHQD) $\left.{ }_{2} \mathrm{PHAL}\right)$ and basic buffer $\mathrm{K}_{2} \mathrm{CO}_{3}$. B: $\mathrm{RuCl}_{3}(5 \mathrm{~mol} \%), \mathrm{NalO}_{4}(1.5 \mathrm{eq}), \mathrm{CeCl}_{3}(10$ mol\%), $\mathrm{CH}_{3} \mathrm{CN} / \mathrm{AcOEt} /$ water (3/3/1), rt, 30 min. C: $\mathrm{K}_{2} \mathrm{OsO}_{4}(5 \mathrm{~mol} \%), \mathrm{NMO}$ (1.28 eq), acetone/water (4/1), rt, 18h. D: $\mathrm{K}_{2} \mathrm{OsO}_{4}$ (0.6 mol\%), NMO (1.1 eq), $\mathrm{EtOH} / \mathrm{H}_{2} \mathrm{O}$ (1/1), citric acid (0.75 eq), rt, $18 \mathrm{~h}$.

[a] Determined by ${ }^{1} \mathrm{H}$ NMR of crude reaction mixture. [b] Isolated as a pure mixture of diastereomers. [c] Major diastereomer being the D-ribono-1,4lactone derivative. [d] Determined by ${ }^{1} \mathrm{H}$ NMR of crude reaction mixture. [e] Determined by HPLC of crude reaction mixture.

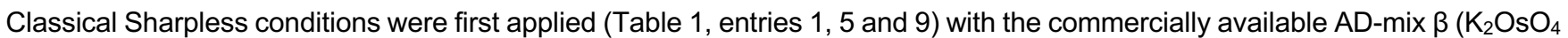
or $\mathrm{OsO}_{4}, \mathrm{~K}_{3} \mathrm{Fe}(\mathrm{CN})_{6}$, chiral ligand $\left.(\mathrm{DHQD})_{2} \mathrm{PHAL}\right)$ and basic buffer $\mathrm{K}_{2} \mathrm{CO}_{3}$. Nevertheless, under such conditions no dihydroxylation was observed. Ruthenium-catalyzed syn-dihydroxylation using an in situ generation of the oxidant specie $\mathrm{RuO}_{4}{ }^{28}\left(\mathrm{RuCl}_{3} .5 \mathrm{H}_{2} \mathrm{O}, \mathrm{NalO}_{4}, \mathrm{CeCl}_{3}, \mathrm{CH}_{3} \mathrm{CN}\right.$-AcOEt-water (3/3/1)) was also investigated (Table 1, entries 2, 6 and 10). Under these conditions, HBO-TBDMS-2OH, HBO-TBDPS-2OH and HBO-Bn-2OH were obtained in 60, 62 and $60 \%$ yields, respectively, comparable to that obtained with $\mathrm{KMnO}_{4} /$ dicyclohexano-18-crown-6 ether ${ }^{24}$. Upjohn dihydroxylation conditions, ${ }^{29-}$ 31 involving osmium tetroxide as catalyst and $N$-methylmorpholine- $N$-oxide (NMO) as oxidant, were then investigated (Table 1 , entries 3, 7 and 11). Among the different solvent mixtures tested (i.e., methanol, acetone-water and acetone-water-butanol), acetone/water proved the most relevant one and gave access to dihydroxylated derivatives of HBO-TBDMS (HBO-TBDMS2OH), HBO-TBDPS (HBO-TBDPS-2OH), and HBO-Bn (HBO-Bn-2OH) in moderate yields, 50, 55 and $12 \%$ respectively. As classical Upjohn conditions did not lead to higher yields, modified-Upjohn conditions were applied as the addition of citric acid had been proven beneficial. ${ }^{31}$ After being optimized, this room temperature procedure provided the corresponding 5-O-protected dihydroxylactones in excellent yields (HBO-TBDMS-2OH: 88\%, overall yield from LGO: 58\%; HBO-TBDPS-2OH: 89\%, overall yield from LGO: 61\%; HBO-Bn-2OH: 89\%, overall yield from LGO: 40\%) (Table 2, entries 4, 8 and 12). The diastereomeric excesses were first evaluated by performing ${ }^{1} \mathrm{H}$ NMR spectroscopy of the crude reaction mixtures by looking at the signal of the protons of the $\mathrm{C}_{2}$ at the $\gamma$ position. Calculations showed that the syn-dihydroxylation proceeds with d.r. between 82:18 and $97: 3$ depending on the protecting group used, demonstrating the average to high diastereoselectivity of the syn-dihydroxylation. 
As expected, the higher steric hindrance of tert-butyldimethyl silyl and tert-butyldiphenyl silyl groups provides the highest d.r. compared to the less bulky "flat" benzyl group. Nevertheless, because of partial overlapping of signals in ${ }^{1} \mathrm{H}$ NMR spectroscopy, d.r. needed to be confirmed by another technique.

To confirm the diastereoisomeric ratios measured by ${ }^{1} \mathrm{H}$ NMR spectroscopy, HPLC analysis of the crude dihydroxylation mixtures was carried out. To do so, the two pure diastereomers (i.e., protected D-ribono-1,4-lactone and D-lyxono-1,4-lactone) were required for every single protected HBO-R. As these compounds were not commercially available, we first dedicated ourselves to their synthesis starting from readily available commercial D-ribono-1,4-lactone, D-lyxono-1,4-lactone and Dgulonolactone.

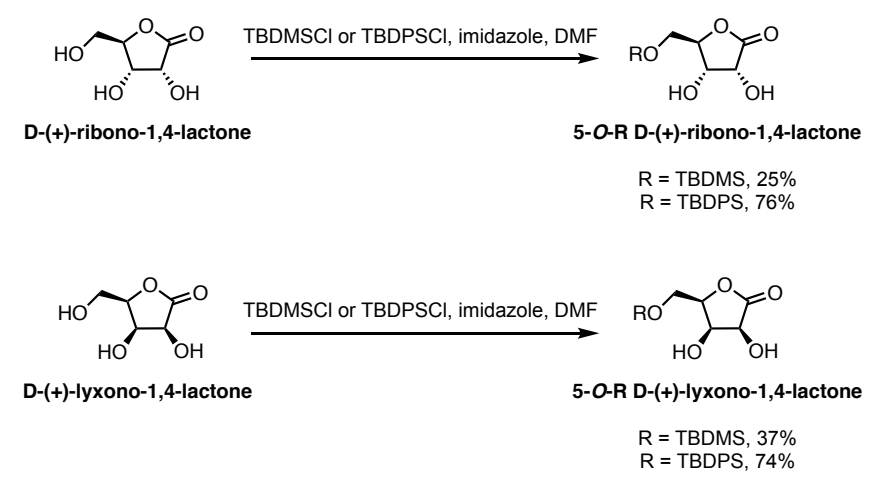

Scheme 5. Preparation of the silylated standards for HPLC

5-O-tert-butyldimethylsilyl-D-ribonolactone and 5-O-tert-butyldimethylsilyl-D-lyxono-1,4-lactone were readily obtained in one step through the silylation of D-ribono-1,4-lactone and D-lyxono-1,4-lactone, respectively (TDMSCl, imidazole, DMF, 25\% yield for ribono-1,4-lactone and $37 \%$ for lyxono-1,4-lactone) (Scheme 5). The same strategy was applied for the synthesis of the TBDPS derivatives and provided 5-O-tert-butyldiphenylsilyl-D-ribonolactone and 5-O-tert-butyldiphenylsilyl-D-lyxono-1,4lactone in 76 and $74 \%$ yield, respectively. The synthesis of the benzylated standards proved less straightforward and required multi-step pathways. The three-step preparation of 5-O-benzyl-D-ribono-1,4-lactone started with the selective acetalization of D-ribono-1,4-lactone into 2,3-O-isopropylidene-D-ribono-1,4-lactone ( $\mathrm{HCl}$, acetone, 75\%) (Scheme 6). The latter was then benzylated $(\mathrm{BnBr}, \mathrm{NaH}, \mathrm{DMF}, 34 \%)^{32}$ and the resulting intermediate was hydrolyzed (Montmorillonite $\mathrm{K} 10, \mathrm{EtOH}, 86 \%$ ) to provide 5-O-benzyl-D-ribonolactone. The preparation of 5-O-benzyl-D-lyxono-1,4-lactone was even more tedious and required a six-step pathway. L-gulonolactone was first bis-acetalized (acetone, $p-\mathrm{TsOH}, 2,2-\mathrm{DMP}$ ) to provide crude 2,3-5,6-di-Oisopropylidene-L-gulonolactone which then underwent a selective hydrolysis of the ketal at the 5,6 -positions (AcOH/water) giving access to 2,3-O-isopropylidene-L-gulonolactone (61\% from L-gulonolactone). The 5,6-diol moiety of the latter was then submitted to an oxidative cleavage (periodic acid, $\mathrm{THF})^{33}$ and the resulting crude aldehyde was readily reduced $\left(\mathrm{NaBH}_{3} \mathrm{CN}\right.$, $\mathrm{AcOH}$ ) to provide 2,3-O-isopropylidene-D-lyxono-1,4-lactone (64\% over the two steps). Finally, the benzylation of the primary alcohol at $\mathrm{C}-6(\mathrm{BnBr}, \mathrm{NaH}, \mathrm{DMF}, 24 \%)$ followed by the hydrolysis of the ketal $(\mathrm{AcOH}$, water, 73\%) led to 5-O-benzyl-D-lyxono1,4-lactone ( $7 \%$ overall yield from L-gulonolactone).

With all the standards in hand, HPLC analyses of the crude reaction mixture were performed. The d.r. calculated from the chromatograms and reported in Table 1 were similar to those obtained by ${ }^{1} \mathrm{H}$ NMR spectroscopy with values between $82: 18$ and $97: 3$, thus undoubtedly confirming the protecting group-dependency of the syn-dihydroxylation diastereoselectivity toward D-ribono-1,4-lactone scaffold. When compared to the previously reported procedure involving $\mathrm{K}_{2} \mathrm{OsO}_{4}$ and $\mathrm{DCH}-18-\mathrm{crown}^{-6}$ ether, ${ }^{24} \mathrm{RuO}_{4}$-catalyzed and modified-Upjohn syn-dihydroxylations prove as diastereoselective, the latter is nevertheless more efficient with regards to yields.

The fourth and final step of this novel chemo-enzymatic route to D-(+)-ribono-1,4-lactone from LGO consisted in the removal of the protecting groups at the 5-O position of the HBO-R-2OH compounds. It is noteworthy to mention that the cleavage procedures have been performed on the mixtures of diastereomers and not on isolated protected D-ribono-1,4-lactones. Deprotection of the benzyl group of $\mathrm{HBO}-\mathbf{B n}-\mathbf{2 O H}$ was readily performed using palladium-catalyzed hydrogenation providing HBO-2OH in 92\% yield (Table 2, entry 1). Silyl ethers cleavage was first attempted under classical deprotection conditions in presence of fluoride anions. Among the various reagents used, KF proved efficient on HBO-TBDPS-2OH, providing D-(+)ribono-1,4-lactone in $52 \%$ yield (Table 2 , entry 2 ), while tetra- $n$-butylammonium fluoride (TBAF) allowed the deprotection of HBO-TBDMS-2OH in $68 \%$ yield (Table 2 , entry 6 ). 


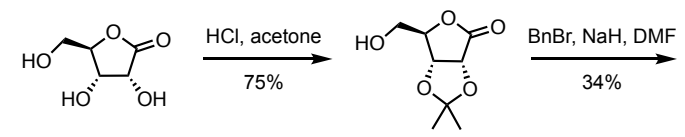

D-(+)-ribono-1,4-lactone

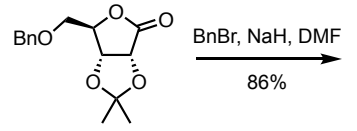<smiles>O=C1O[C@H](COBr)[C@@H](O)[C@H]1O</smiles>

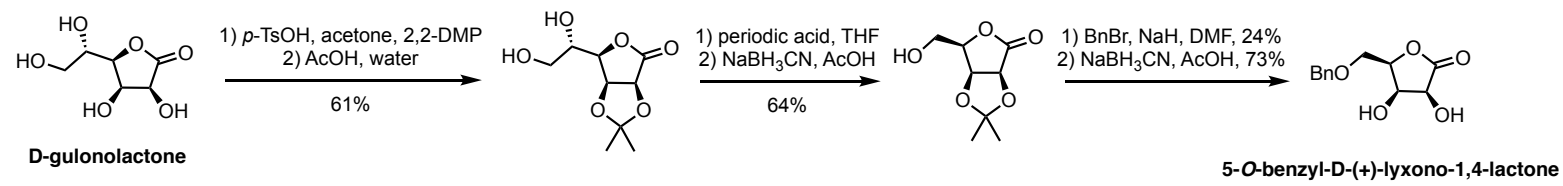

Scheme 6. Preparation of the benzylated standards for HPLC
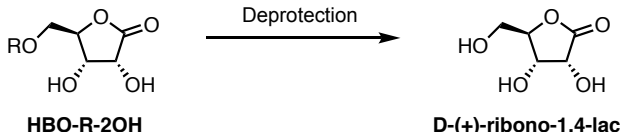

D-(+)-ribono-1,4-lactone

Table 2. Deprotection of HBO-R-2OH

\begin{tabular}{|c|c|c|c|c|}
\hline $\begin{array}{l}\text { Entr } \\
y\end{array}$ & $\begin{array}{l}\text { Substrate } \\
\text { (HBO-R-2OH) }\end{array}$ & Procedure & $\begin{array}{l}\text { Yield } \\
(\%)^{[a]}\end{array}$ & $\begin{array}{l}\text { Overall } \\
\text { yield } \\
\text { from LGO } \\
(\%)\end{array}$ \\
\hline 1 & HBO-Bn-2OH & $\mathrm{H}_{2}, \mathrm{Pd} / \mathrm{C}, \mathrm{EtOH}$ & 92 & 31 \\
\hline 2 & HBO-TBDPS-2OH & $\mathrm{KF}, \mathrm{DMF}$ & 52 & 32 \\
\hline 3 & & $\mathrm{CH}_{3} \mathrm{COCl}, \mathrm{MeOH}$ & 51 & 31 \\
\hline 4 & & $\begin{array}{l}\mathrm{TfOH}-\mathrm{SiO}_{2} \\
\mathrm{MeCN}\end{array}$ & 62 & 38 \\
\hline 5 & & $\begin{array}{c}\text { Montmorillonite } \\
\mathrm{K} 10, \mathrm{MeOH} / \text { water }\end{array}$ & $<10$ & - \\
\hline 6 & HBO-TBDMS-2OH & $\begin{array}{l}\text { TBAF, THF, } \\
\text { DOWEX 50W }\end{array}$ & 68 & 39 \\
\hline 7 & & $\mathrm{CH}_{3} \mathrm{COCl}, \mathrm{MeOH}$ & 37 & 21 \\
\hline 8 & & $\begin{array}{l}\text { Montmorillonite } \\
\mathrm{K} 10, \mathrm{MeOH} / \text { water }\end{array}$ & 77 & 44 \\
\hline
\end{tabular}

[a] Isolated

In the latter case, it is worth noting that the resulting D-ribono-1,4-lactone being highly water-soluble, resin-based post-treatment was used instead of classical aqueous treatment to remove the excess of reagent. Assays using acetyl chloride ${ }^{34}$ and triflic acid supported on silica ${ }^{35}$ as acid catalyst on HBO-TBDPS-2OH resulted in 51 and $62 \%$ yields, respectively (Table 2, entry 3). Successful deprotection of HBO-TBDMS-2OH in 37\% was also observed with acetyl chloride (Table 2, entry 7). Finally, we were pleased to observe that the use of a sustainable and mild procedure ${ }^{36}$ involving Montmorillonite $\mathrm{K} 10$ in a methanol/water mixture allowed the deprotection of HBO-TBDMS-2OH in 77\% (Table 2, entry 8). Unfortunately, the implementation of this procedure on HBO-TBDPS-2OH did not prove successful with only <10\% yield (Table 2, entry 5). Indeed, TBDPS being considerably more stable (ca. 100 times) than TBDMS towards acidic hydrolysis, its removal requires harsher acidic conditions. ${ }^{37}$ 


\section{Conclusion}

This four-step synthetic route from cellulose-based levoglucosenone (LGO) involving (i) $\mathrm{H}_{2} \mathrm{O}_{2}$-mediated Baeyer-Villiger oxidation and (ii) diastereoselective and high yielding modified-Upjohn syn-dihydroxylation as key steps allows to access D-(+)ribono-1,4-lactone with good to excellent diastereoselectivity and in good overall yields using TBDMS (44\% yield, d.r. ca. 94:6), TBDPS (38\%, d.r. ca. 94:6) and $\mathrm{Bn}(31 \%$, d.r. ca. 80:20) protecting group, respectively. Although this new route does not compete with the one-step oxidation of D-ribose into D-(+)-ribono-1,4-lactone (ca. 65\%) in terms of yield, diastereoselectivity and number of steps, not only it uses LGO, a cheaper renewable starting material, but it also allows the straightforward synthesis of 5-O-silylated and benzylated ribono-1,4-lactones which are valuable intermediates for the synthesis of high value added chemicals such as bioactive compounds and functional additives for drugs, food, feed or cosmetics.

\section{Acknowledgements}

The authors are grateful to the Circa Group for providing them with industrial grade levoglucosenone, and to the Région Grand Est, the Conseil Départemental de la Marne, and Grand Reims for their financial support.

\section{Keywords: Chiral pool $\bullet$ Oxidation $•$ Asymmetric synthesis $•$ Dihydroxylation $\bullet$ Substituent effects}

[1] A. Corma, S. Iborra, A. Velty, Chem. Rev. 2007, 107 (6), 2411-2502.

[2] C. Zhou, X. Xia, C.-X. Lin, D.-S. Tong, J. Beltramini, Chem. Soc. Rev. 2011, 40, 5588-5617.

[3] G. W. Huber, S. Iborra, A. Corma, Chem. Rev. 2006, 106 (9), 4044-4098.

[4] M. S. Miftakhov, F. A. Valeev, I. N. Gaisina, Russ. Chem. Rev. 1994, 63 (10), 869-882.

[5] A. V. Bridgwater, D. Meier, D. Radlein, Org. Geochem. 1999, 30 (12), 1479-1493.

[6] Q. Lu, W.-M. Xiong, W.-Z. Li, Q.-X. Guo, X.-F. Zhu, Bioresour. Technol. 2009, 100 (20), 4871-4876.

[7] V. L. Budarin, P. S. Shuttleworth, J. R. Dodson, A. J. Hunt, B. Lanigan, R. Marriott, K. J. Milkowski, A. J. Wilson, S. W. Breeden, J. Fan, E. H. K. Sin, J. H. Clark, Energy Environ. Sci. 2011, 4 (2), 471-479.

[8] X. Hu, L. Wu, Y. Wang, D. Mourant, C. Lievens, R. Gunawan, C.-Z. Li, Green Chem. 2012, 14 (11), 3087-3098.

[9] K. Tomioka, T. Ishiguro, K. Koga, J. Chem. Soc., Chem. Commun. 1979, 652, 652-653.

[10] D. Enders, V. Lausberg, G. Del Signore, O. M. Berner, Synthesis 2002, 4 (15), 515-522.

[11] E. Takashi, M. Katsuya, Y. Hajime, K. Koseki, H. Kawakami, H. Matsushita, Heterocycles 1990, 31, 1585-1588.

[12] a) A. A. M. Peru, A. L. Flourat, C. Gunawan, W. Raverty, M. Jevric, B. Greatrex, F. Allais, Molecules 2016, 21 (8), 1-10; b) F. Allais, A. L. Flourat, A. A. M. Peru, B. Greatrex, R. Warwick, A. Duncan, WO 2016/162646 A1, 2016.

[13] H. Hawakami, T. Ebata, K. Koseki, K. Matsumoto, H. Matsushita, Y. Naoi, K. Itoh, Heterocycles 1990, 31, 2041-2054.

[14] R. Flores, A. Rustullet, R. Alibes, A. Alvarez-Larena, P. de March, M. Figueredo, J. Font, J. Org. Chem. 2011, 76 (13), 5369-5383.

[15] A. Díaz-Rodríguez, Y. S. Sanghvi, S. Fernández, R. F. Schinazi, E. Theodorakis, M. Ferrero, V. Gotor, Org. Biomol. Chem. 2009, 7, $1415-1423$.

[16] A. L. Flourat, A. A. M. Peru, A. R. S. Teixeira, F. Brunissen, F. Allais, Green Chem. 2014, 17 (1), 404-412.

[17] A. R. S. Teixeira, A. L. Flourat, A. A. M. Peru, F. Brunissen, F. Allais, Front. Chem. 2016, 4, 1-11.

[18] F. Allais, A. L. Flourat, A. A. M. Peru, A. R. S. Teixeira, F. Brunissen, H. E. Spinnler, WO 2015/165957 A1, 2015.

[19] a) G. Bonneau, A. A. M. Peru, A. L. Flourat, F. Allais, Green Chem. 2018, 20, 2455-2458; (b) F. Allais, G. Bonneau, A. L. Flourat, A. A. M. Peru, WO2018007764 A1, 2018

[20] G. P. Silveira, H. M. Cardozo, T. A. Rossa, M. M. Sa, Curr. Org. Synth. 2015, 12, 584-602.

[21] A. Fürstner, K. Radkowski, C. Wirtz, R. Goddard, C. W. Lehmann, R. Mynott, J. Am. Chem. Soc. 2002, 124, 7061-7069.

[22] A. Sanchez-Eleuterio, W. H. Garcia-Santos, H. Diaz-Salaza, M. Hernandez-Rodriguez, A. Cordero-Vargas, J. Org. Chem. 2017, 82, 8464-8475.

[23] H. M. Cardozo, T. F. Ribeiro, M. M. Sa, D. Sebrao, M. G. Nascimento, G. P. Silveira, J. Braz. Chem. Soc. 2015, 26 (4), $755-764$.

[24] T. Mukaiyama, F. Tabusa, K. Suzuki, Chem. Lett. 1983, 173-174.

[25] K. Yamada, H. Fujita, M. Kunishima, Org. Lett. 2012, 14, 5026-5029.

[26] E. N. Jacobsen, I. Marko, W. S. Mungall, G. Schroder, K. B. Sharpless, J. Am. Chem. Soc. 1988, 110, 1968-1970.

[27] H. C. Kolb, M. S. Van Nieuwenhze, K. B. Sharpless, Chem. Rev. 1994, 94, 2483-2547.

[28] B. Plietker, M. Niggemann, Org. Biomol. Chem. 2004, 2, 2403-2407.

[29] V. Van Rheenen, R. C. Kelly, D. Y. Cha, Tetrahedron Lett. 1976, 23, 1973-1976.

[30] V. G. Boojamra, K. Y. Lin, R. L. Mackman, D. Y. Markevitch, O. V. Petrakosvsky, US2009202470A1, 2009.

[31] P. Dupau, R. Epple, A. A. Thomas, V. V. Fokin, K. B. Sharpless, Adv. Synth. Catal. 2002, 344 (3-4), 421-433.

[32] M. Shiozaki, Carbohydr. Res. 2002, 337, 2077-2088.

[33] G. W. J. Fleet, N. G. Ramsden, D. R. Witty, Tetrahedron 1989, 45, 319-326.

[34] A. T. Khan, E. Mondal, Synlett 2003, 5, 694-698.

[35] S. Yan, N. Ding, W. Zhang, P. Wang, Y. Li, M. Li, Carbohydr. Res. 2012, 354, 6-20.

[36] J.-O. Asakura, M. J. Robins, Y. Asaka, T. H. Kim, J. Org. Chem. 1996, 61, 9026-9027.

[37] N. Kagawa, M. Ihara, M. Toyota, Org. Lett. 2006, 8, 875-878. 